\title{
Characterization of renin mRNA expression and enzyme activity in rat and mouse mesangial cells
}

A.Q. Andrade, D.E. Casarini,

\author{
Disciplina de Nefrologia, Escola Paulista de M edicina, \\ Universidade Federal de São Paulo, São Paulo, SP, Brasil
}

\begin{abstract}
Correspondence
M.A. Boim

Disciplina de Nefrologia

EPM, UNIFESP

Rua Botucatu, 740

04023-900 São Paulo, SP

Brasil

Fax: + 55-11-5573-9652

E-mail: mirian@ nefro.epm.br

Research supported by CNPq and Fundação O swaldo Ramos, UNIFESP. Publication supported by FAPESP.
\end{abstract}

Received April 11, 2001 Accepted 0 ctober 2, 2001

\section{Abstract}

Renin is an enzyme involved in the stepwise generation of angiotensin II. Juxtaglomerular cells are the main source of plasma renin, but renin activity has been detected in other cell types. In the present study we evaluated the presence of renin mRNA in adult male Wistar rat and mouse (C-57 Black/6) mesangial cells (MC) and their ability to process, store and release both the active and inactive forms of the enzyme. Active renin and total renin content obtained after trypsin treatment were estimated by angiotensinogen consumption analyzed by SDS-PAGE electrophoresis and quantified by angiotensin I generation by HPLC. Renin mRNA, detected by RT-PCR, was present in both rat and mouse $\mathrm{MC}$ under basal conditions. Active renin was significantly higher $(\mathrm{P}<0.05)$ in the cell lysate $\left(43.5 \pm 5.7 \mathrm{ng} \mathrm{h}^{-1} 10^{6}\right.$ cells) than in the culture medium ( $12.5 \pm 2.5 \mathrm{ng} \mathrm{h}^{-1} 10^{6}$ cells $)$. Inactive prorenin content was similar for the intra- and extracellular compartments $\left(9.7 \pm 3.1\right.$ and $3.9 \pm 0.9 \mathrm{ng} \mathrm{h}^{-1} 10^{6}$ cells $)$. Free active renin was the predominant form found in both cell compartments. These results indicate that $\mathrm{MC}$ in culture are able to synthesize and translate renin mRNA probably as inactive prorenin which is mostly processed to active renin inside the cell. MC secrete both forms of the enzyme but at a lower level compared with intracellular content, suggesting that the main role of renin synthesized by MC may be the intracellular generation of angiotensin II.

\section{Introduction}

Systemic angiotensin II plays a pivotal role in the regulation of blood pressure and in fluid and electrolyte homeostasis. The renin-angiotensin system (RAS) consists of four main proteins: renin, angiotensinogen, angiotensin I-converting enzyme (ACE) and angiotensin II receptor. Renin is a rate-limiting enzyme in the synthesis of angiotensin II (1) and juxtaglomerular cells in the kidney are the main source of plasma renin, responsible for cleavage of angiotensinogen into angiotensin I, initiating the cascade for systemic angiotensin II formation. About $80 \%$ of intracellular renin has little or no enzymatic activity and is called inactive renin or prorenin (2). Inactive renin can be converted into the active form through limited proteolysis at physiological $\mathrm{pH}$ by tissue proteases such as trypsin and kallikreins $(3,4)$, but probably by cathepsin B in vivo (5). 
In addition to systemic angiotensin II generation, increasing evidence has suggested that several organs and tissues are able to locally synthesize angiotensin II (6). In the kidney, proximal and distal tubular epithelial cells express genes encoding for all RAS components (7). In addition, it has been recently demonstrated that human mesangial cells express mRNA for renin, angiotensinogen and ACE $(8,9)$. Moreover, renin activity has been also demonstrated in these cells (10) although it is not known if mesangial cells, like juxtaglomerular cells, are able to store, process and secrete the active form of the enzyme, which may constitute a local endocrine system serving paracrine and autocrine functions. Thus, the objectives of the present study were to determine if mouse and rat mesangial cells in culture are able to express and translate renin mRNA and secrete the active form of renin.

\section{Material and Methods}

\section{Primary culture of rat and mouse mesangial cells}

Glomerular mesangial cells were cultured from kidneys freshly removed from normal adult male Wistar rats and mice (C-57 Black/ 6) as previously described (11). Briefly, kidney cortex was macrodissected, fragmented, forced through a graded series of stainlesssteel sieves (60, 100, and 200 meshes), and rinsed with RPMI 1640 culture medium. The glomeruli were then collected from the surface of the third sieve and forced through a $25 \times 7$ gauge needle for full decapsulation. Glomeruli were plated at a density of $\sim 300$ glomeruli/cm onto RPMI 1640 supplemented with $20 \% \mathrm{FCS}, 50 \mathrm{U} / \mathrm{ml}$ penicillin, $2.6 \mathrm{~g}$ acid HEPES and $2 \mathrm{mM}$ glutamine. All reagents were from Sigma (St. Louis, MO, USA). Culture flasks were kept in a 95\% air and 5\% $\mathrm{CO}_{2}$ humidified environment at $37^{\circ} \mathrm{C}$. The medium was replaced every $36 \mathrm{~h}$. After 3 weeks cells were harvested with trypsin and the subcultures were grown in the same culture medium. Cells were used between the 3 rd and 5th subculture. Mesangial cells were characterized by previously established criteria, including morphological appearance of stellate shape, positive immunofluorescence staining for actin and myosin and negative staining for human factor VIII (11).

\section{Total RNA extraction}

Total RNA was isolated from rat and mouse kidney cortex and from mesangial cells by the guanidine isothiocyanate-cesium chloride method. The RNA pellet was dissolved in RNase-free water and RNA concentration was estimated with a spectrophotometer (Gene Quant RNA/DNA calculator, Amersham Pharmacia Biotech, Uppsala, Sweden).

$R T-P C R$. Two micrograms of total RNA was reverse transcribed by the addition of a mix containing $0.5 \mathrm{mg} / \mathrm{ml}$ oligo $\mathrm{d}(\mathrm{T})$ primer (Pharmacia Biotech), $10 \mathrm{mM}$ DTT, $0.5 \mathrm{mM}$ mixed dNTPs (Pharmacia Biotech), and 200 $\mathrm{U}$ reverse transcriptase (SuperScript RT, Gibco-BRL, São Paulo, SP, Brazil). The mixture was incubated at $37^{\circ} \mathrm{C}$ for $1 \mathrm{~h}$. PCR was performed in a thermal cycler (model PTC100, MJ Research, Watertown, MA, USA) using $2 \mu \mathrm{l}$ of cDNA in a total volume of $20 \mu \mathrm{l}$ containing 1.0-2.5 mM MgCl (optimized for each pair primer), $0.5 \mathrm{mM}$ of each primer, $0.5 \mathrm{mM}$ dNTP mix and 0.5 U Taq DNA polymerase (Pharmacia Biotech). Primer sequences and amplification conditions for each primer pair are shown in Table 1.

Negative controls were included in each set of PCR assays where cDNA was substituted for water as a control for contamination from exogenous sources. In addition, reverse transcriptase was omitted in some samples as a negative control for amplification of genomic DNA. Positive controls included amplification of kidney cortex cDNA and the efficiency of the reverse transcriptase reaction was monitored by $\beta$ actin cDNA 
amplification. PCR products were electrophoresed on $1 \%$ agarose gel and visualized by ethidium bromide staining under UV light.

\section{Intracellular renin activity}

Total intracellular renin activity was determined in both rat and mouse mesangial cells on the basis of angiotensinogen consumption. Cells were rinsed twice with PBS and lysed with $1 \mathrm{mM}$ Tris-HCl buffer. Cell homogenates were treated with enzymatic inhibitors (50 mM EDTA, $312 \mathrm{mM}$ PMFS, $1.0 \mathrm{mM}$ Ophe and $200 \mathrm{mM}$ DTT) specific for enzymes able to cleave renin and angiotensinogen, including serine-, thiol- and metalloproteinases. In addition, a homogenate aliquot was treated with trypsin $(50 \mu \mathrm{g} / \mathrm{ml})$ for $16-18 \mathrm{~h}$ at $37^{\circ} \mathrm{C}$ in order to activate inactive prerenin. Samples were then incubated with sheep angiotensinogen $(1 \mathrm{mg} / \mathrm{ml})$ for different periods of time $(0,4,8,12$ and $24 \mathrm{~h})$ at $37^{\circ} \mathrm{C}$ and the reaction was interrupted by the addition of $50 \% \mathrm{H}_{3} \mathrm{PO}_{4}$. Angiotensinogen consumption was analyzed by SDS-PAGE on $7.5 \%$ polyacrylamide slab gel by the method of Laemmli (12), stained with a Silver Stain kit (BioRad Laboratories, Hercules, CA, USA) and semi-quantified by densitometric analyses (Quik scan).

\section{Renin content analysis}

The content of active and inactive forms of renin was determined and quantified in rat primary mesangial cells in the intracellular compartment and in the culture medium, characterizing the secreted forms. The culture medium was collected and stored at $-70^{\circ} \mathrm{C}$ until the time for use. Cells were rinsed with PBS, lysed with $1 \mathrm{mM}$ Tris-HCl buffer and stored until the time for use. Total content of renin included active renin (free form) and the inactive prorenin form, activated with $10 \mu \mathrm{l}$ of trypsin $(50 \mu \mathrm{g} / \mathrm{ml})$ for $16-18 \mathrm{~h}$ at $37^{\circ} \mathrm{C}$. The free renin (active) content was evaluated in the absence of trypsin. In addition, cell homogenate and culture medium were incubated with enzymatic inhibitors as described above to protect the angiotensin I released. The content of renin was estimated by angiotensin I generation when cell lysate or culture medium was incubated with $10 \mu \mathrm{l}$ of a synthetic tetradecapeptide substrate, 1 $\mathrm{mg} / \mathrm{ml}$ (kindly supplied by Dr. Luis Juliano, Biophysics Department, UNIFESP, São Paulo, SP, Brazil) for 0, 4, 8, 12 and 24 h at $37^{\circ} \mathrm{C}$. The reaction was interrupted with 10 $\mu \mathrm{l}$ of $50 \% \mathrm{H}_{3} \mathrm{PO}_{4}$. After interruption of the reaction at different times of incubation, 100 $\mu 1$ of each sample was filtered and injected into the HPLC system. The released angiotensin I peptide was analyzed by reversed phase HPLC using an aquapore ODS 300 column equilibrated with $0.1 \%$ phosphoric acid containing $5 \%$ acetonitrile $(\mathrm{v} / \mathrm{v})$. Angiotensin I was separated by isocratic elution for $5 \mathrm{~min}$ followed by a 20 -min linear gradient of $5-35 \%$ acetonitrile in $0.1 \%$ phosphoric acid $(\mathrm{v} / \mathrm{v})$ at $1.5 \mathrm{ml} / \mathrm{min}$. The chromatographic profile of each sample was compared with that obtained for standard samples

Table 1. PCR primer sequences and reaction conditions.

\begin{tabular}{|c|c|c|}
\hline & Rat & Mouse \\
\hline Sense primer & 5'CAGTACTATGGTAGATCGGCT3' & 5'CCAAGTTTGACGGTGTTC3' \\
\hline Antisense primer & 5'ACTCCATCAACAGCCTGAGC $3^{\prime}$ & 5'CAGAGCCTTCTTCAGATAGC3' \\
\hline Denaturation & $94^{\circ} \mathrm{C}$ & $94^{\circ} \mathrm{C}$ \\
\hline Annealing & $50^{\circ} \mathrm{C}$ & $58^{\circ} \mathrm{C}$ \\
\hline Elongation & $72^{\circ} \mathrm{C}$ & $72^{\circ} \mathrm{C}$ \\
\hline $\mathrm{MgCl}_{2}$ concentration & $1.0 \mathrm{mM}$ & $1.5 \mathrm{mM}$ \\
\hline Product size & $362 \mathrm{bp}$ & 291 bp \\
\hline
\end{tabular}


Figure 1. RT-PCR amplification for renin mRNA using primers for mice (panel A) and rats (panel B) from whole kidney and mesangial cells (MC). RT-represents samples with absence of reverse transcriptase and served as negative control for each reverse transcribed $(\mathrm{RT}+)$ sample. containing angiotensinogen (retention time $=20.23 \mathrm{~min}$ ) and angiotensin I (retention time $=19.59 \mathrm{~min}$ ) at absorbance of $240 \mathrm{~nm}$, AUF $=0.02$. Peptide fragments were identified by elution position and quantified by integration area using repeated injections of standard peptide solution to correct for small differences in retention time $(<6 \%)$ and peak height $(<5 \%)$.

\section{Results}

\section{PCR amplification of renin mRNA from rat and mouse mesangial cells}

$R T-P C R$. Figure 1 shows a representative gel of RT-PCR-amplified products for mouse $(1 \mathrm{~A})$ and rat $(1 \mathrm{~B})$ renin cDNA. cDNA obtained from whole kidney was used as positive control. The negative control for each cDNA synthesis reaction consisted of the absence of reverse transcriptase. The specific primer pairs for different animal species were able to amplify the expected product size for mouse (291 bp) and rat (362 bp) mesangial cells.

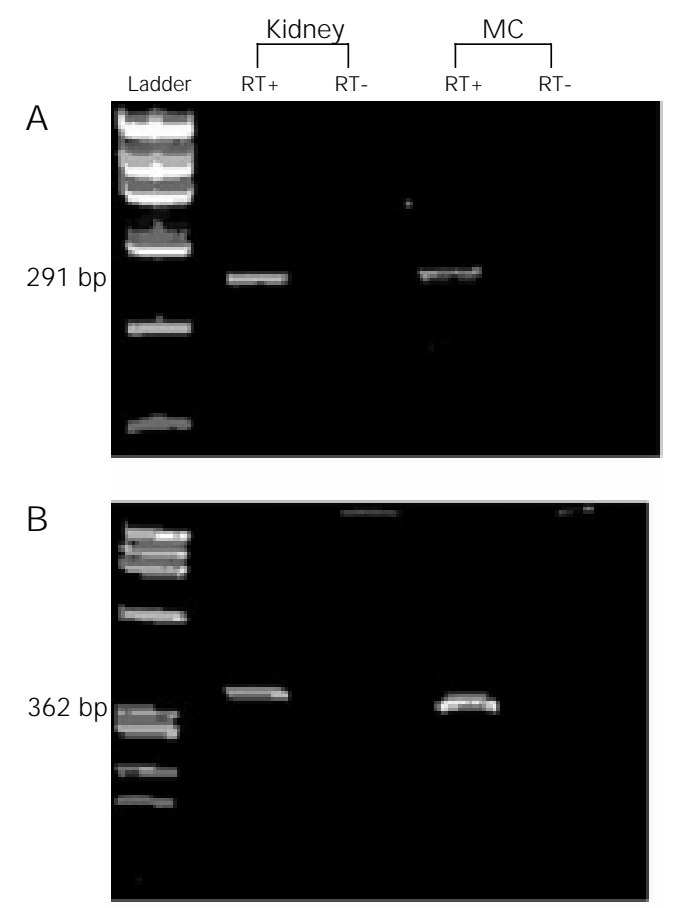

\section{Renin activity}

Intracellular renin activity present in rat and mouse (Figure 2) mesangial cells was estimated by angiotensinogen consumption and visualized on polyacrylamide gel. Densitometric analysis showed a slow but progressive reduction in band intensity in the presence of basal renin activity (panel A). The consumption was accelerated when inactive renin was pre-activated with trypsin (panel B), indicating that mesangial cells store renin in its inactive form, but ready to be activated.

\section{HPLC analyses}

The generation of angiotensin I was used to estimate active and total intracellular renin activity. Figure 3 shows a representative experiment analyzing HPLC-injected cell homogenate samples preincubated with trypsin and then incubated with angiotensinogen to determine total renin activity. As can be seen, the angiotensinogen peak was reduced and the angiotensin I peak was increased over time $(4,8,12$ and $24 \mathrm{~h})$. After $24 \mathrm{~h}$ of incubation, the angiotensinogen peak almost disappeared while the angiotensin I peak was substantially increased, indicating that a substantial quantity of angiotensinogen was hydrolyzed, releasing angiotensin I.

\section{Q uantification of stored and secreted forms of renin}

Based on the HPLC profiles of the released angiotensin I, the relative content of active and inactive forms of renin present in the intracellular compartment and in the culture medium was quantified in rat mesangial cells. Results are reported as $\mathrm{ng} \mathrm{h}^{-1} 10^{6}$ cells (Table 2 and Figure 4). Inactive prorenin content was estimated from the difference between total and active renin. Mean intracellular active renin content was $43.5 \pm 5.7$ ng h $\mathrm{h}^{-1} 10^{6}$ cells, corresponding to $83 \pm 5 \%$ of 

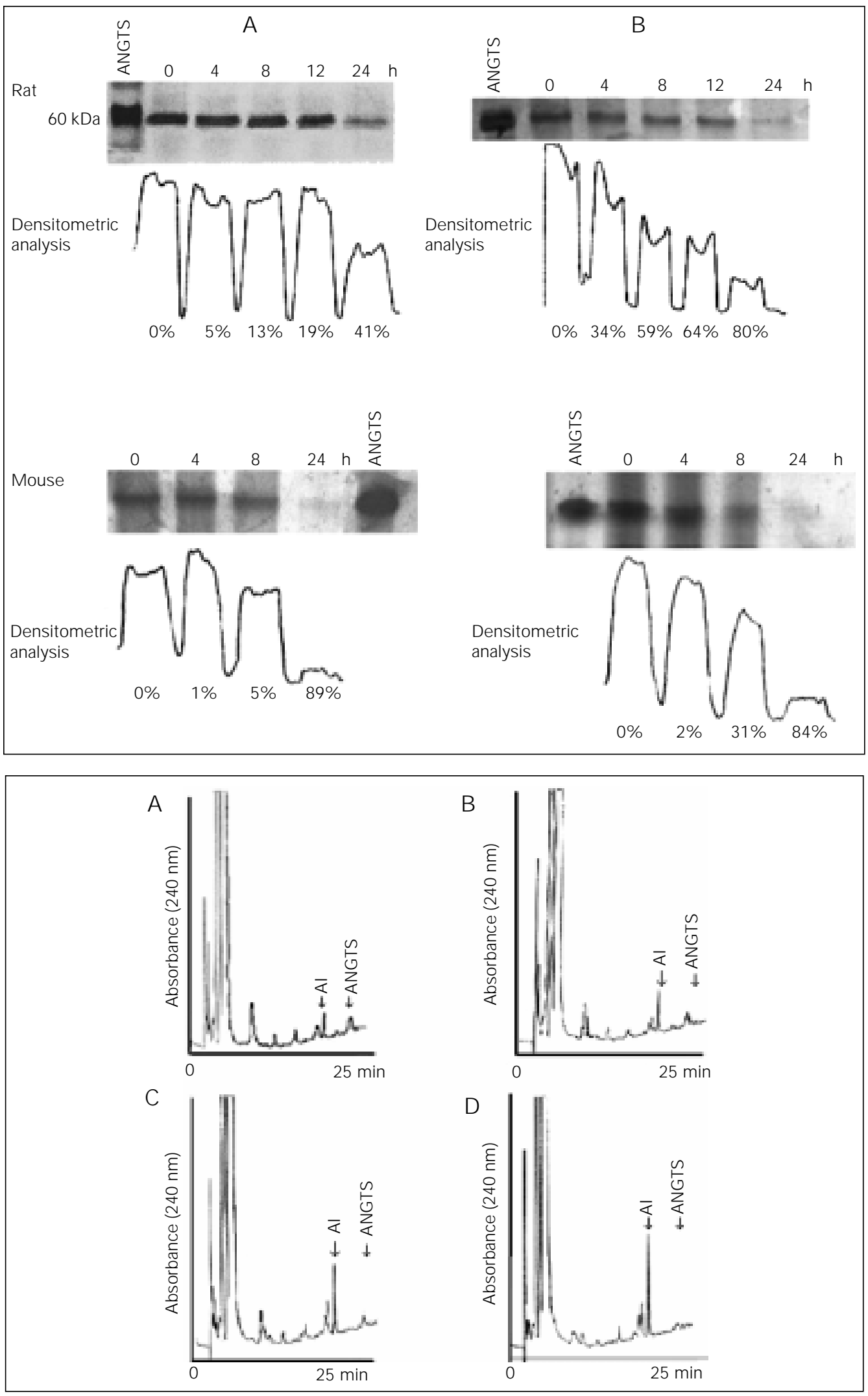

Figure 2. SDS-PAGE of angiotensinogen (ANGTS) hydrolysis by active free renin (panel $A$ ) and total renin (panel $B$ ) present in the intracellular compartment of rat and mouse mesangial cells.

Figure 3. HPLC profile showing the consumption of angiotensinogen (ANGTS) and generation of angiotensin I (Al). Angiotensinogen was incubated with renin from mesangial cells for $4,8,12$ and $24 \mathrm{~h}$ (panels $\mathrm{A}, \mathrm{B}, \mathrm{C}$ and $\mathrm{D}$, respectively). The retention time was 19.59 min for $\mathrm{Al}$ and 20.23 min for ANGTS. 
Table 2. Content of active and inactive renin forms ( $\mathrm{ng} \mathrm{h}^{-1} 10^{6}$ cells) in the intracellular compartment and in culture medium for rat primary mesangial cells.

\begin{tabular}{|c|c|c|c|c|c|}
\hline \multirow[t]{2}{*}{ Compartment } & \multicolumn{2}{|c|}{ Active renin } & \multicolumn{2}{|c|}{ Inactive renin } & \multirow[t]{2}{*}{ Total } \\
\hline & $\begin{array}{c}\mathrm{ng} \mathrm{h}^{-1} \\
10^{6} \text { cells }\end{array}$ & $\%$ & $\begin{array}{c}\mathrm{ng} \mathrm{h}^{-1} \\
10^{6} \text { cells }\end{array}$ & $\%$ & \\
\hline Intracellular $(\mathrm{N}=6)$ & $43.5 \pm 5.7$ & $83 \pm 5$ & $9.7 \pm 3.1$ & $17 \pm 5$ & $53.2 \pm 7.3$ \\
\hline Extracellular $(\mathrm{N}=4)$ & $12.5 \pm 2.5^{*}$ & $76 \pm 6$ & $3.9 \pm 0.9$ & $24 \pm 1$ & $16.4 \pm 2.9 *$ \\
\hline
\end{tabular}

$* \mathrm{P}<0.05$ vs intracellular (Student t-test).

Figure 4. Relative content of active renin and inactive renin peptides in the intracellular compartment and in culture medium (secreted forms).

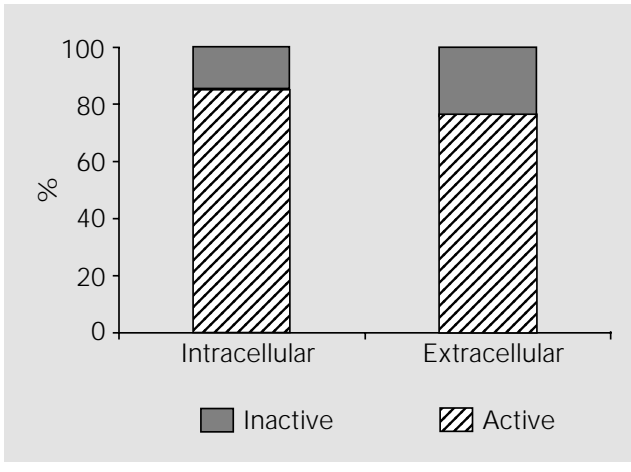

total renin content, while prorenin content $\left(9.7 \pm 3.1 \mathrm{ng} \mathrm{h}^{-1} 10^{6}\right.$ cells) corresponded to $17 \pm 5 \%$. In the culture medium the predominant form was also active renin $(76 \pm 6 \%)$ compared with inactive prorenin $(24 \pm 1 \%)$. However, the secreted forms of both active and inactive renins were present at lower levels compared with intracellular levels, especially active renin $(12.5 \pm 2.5$ vs $43.5 \pm$ $5.7 \mathrm{ng} \mathrm{h}^{-1} 10^{6}$ cells, $\mathrm{P}<0.05$ ).

\section{Discussion}

In juxtaglomerular cells, renin is first synthesized as the protein precursor preprorenin. In rough endoplasmic reticulum, the signal sequence is excised from preprorenin to yield prorenin, the inactive form of the enzyme (13-15). It has been demonstrated that the partial proteolytic activation of prorenin occurs within maturing secretory granules responsible for constitutively releasing both the inactive and active forms of renin. Active renin is also released by juxtaglomerular cells from mature secretory gran- ules by a regulated pathway $(16,17)$. In addition to juxtaglomerular cells, renin activity has been demonstrated in other cell types including kidney cells. Since the secretory function of mesangial cells has been implicated in several autocrine and paracrine activities, the present study evaluated the ability of mouse and rat mesangial cells to express renin mRNA as well as to synthesize, store and secrete both the active (renin) and inactive (prorenin) forms of the enzyme.

The RT-PCR amplification products obtained from mouse and rat mesangial cell cDNAs using specific primers indicated that both cell populations are able to constitutively express renin mRNA. Renin activity has been detected in rat and human cultured mesangial cells $(10,18)$. The renin activity in these cells may derive from intracellular synthesis of renin by renin gene activation or from an extracellular source (culture medium) or from a "renin-like" enzyme, as suggested by Shenoy and Cassis (19) for brown adipose tissue. However, the presence of renin mRNA has been demonstrated in human glomerular epithelial and mesangial cells in culture but apparently at very low levels since it was necessary to use the highly sensitive nested PCR technique to detect renin mRNA under normal conditions (8). In contrast, in the present study a simple RTPCR was sufficient to detect renin mRNA in rat and mouse mesangial cells under basal conditions. Whether the constitutive transcription of the renin gene in rat and mouse mesangial cells is higher than in human mesangial cells in culture cannot be determined from these studies, but the data strongly suggest that the renin activity previously detected in these cells is a consequence of renin gene activation.

In order to determine if renin gene transcription in mesangial cells, like in juxtaglomerular cells, results initially in inactive prorenin and if these cells have the ability to process prorenin to active renin, we evaluated free renin activity content and the total 
content of renin after preactivation of prorenin with trypsin. Intracellular renin activity was higher in the presence of trypsin, indicating that mesangial cells may store and process the inactive form of the enzyme. However, the predominant form found in the cell lysate under basal conditions was active renin, responsible for $\sim 85 \%$ of total intracellular renin activity. This result agrees with previous data obtained for human mesangial cells (10) or other renin-producing cell types including juxtaglomerular cells (20-22).

The presence of renin activity was also evaluated in the culture medium in order to characterize the secreted forms of the enzyme. The levels of both renin and prorenin were much lower than those found in the intracellular compartment. However, the predominant secreted form was active renin, corresponding to $75 \%$ of total renin activity. In contrast, many cell types secrete mainly inactive prorenin. Juxtaglomerular cells, the main source of circulating renin, secrete both active and inactive prorenin, but the inactive renin can be present at three to five times the level of active renin in the circulation of humans (15). The reason why these cells secrete large quantities of inactive enzyme is not clear, since prorenin appears not to be activated in the circulation $(23,24)$ or to act as an endogenous antagonist for the effects of renin, at least in the vascular wall (25). The present results suggest that the main role of renin produced by mesangial cells may be the intracellular generation of angiotensin II, since only a minor quantity of active renin appears to be secreted by mesangial cells. Moreover, both ACE and angiotensinogen have been detected in mesangial cells in culture $(8,9)$, and therefore these cells have all the components necessary to locally synthesize angiotensin II independently of systemic and/or other tissues. Although at low levels, both forms of renin were found in culture medium. Whether these secreted forms have physiological and/or pathophysiological implications needs further investigation.

Renin activity present in the cell lysate was intensified after activation of prorenin with trypsin since the consumption of angiotensinogen was faster after activation, suggesting that mesangial cells are able to store renin in the inactive form, but ready to be activated under a stimulus.

These results indicate that mesangial cells are able to constitutively synthesize and process prorenin to active renin in the intracellular compartment and also to secrete both forms of the enzyme.

\section{References}

1. Reudelhuber TL (1995). Molecular biology of renin. In: Schlöndorff D \& Bonventre JV (Editors), Molecular Nephrology. Marcel Dekker Inc., New York, NY, USA.

2. Skinner SL, Cran EJ , Gibson R, Taylor R, Walters WAW \& Catt KJ (1975). Angiotensin I and angiotensin II, active and inactive renin substrate, renin activity and angiotensinase in human liquor amnii and plasma. American J ournal of Obstetrics and Gynecology, 121: 626-630.

3. Cooper RM, Munay GE \& Osmond DH (1977). Trypsin induced activation of renin precursor in plasma of normal and anephric man. Circulation Research, 40 (Suppl 1): $71-79$.

4. Sealey J E, Atlas SA, Laragh J H, Oza NB \&
Ryan J W (1978). Human urinary kallikrein converts inactive renin to active renin and is a possible physiological activator of renin. Nature, 275: 144-145.

5. Neves FAR, Duncan KG \& Baxter JD (1996). Cathepsin $B$ is a prorenin processing enzyme. Hypertension, 27: 514-517.

6. Pieruzzi F, Abassi ZA \& Keiser HR (1995). Expression of renin-angiotensin system components in the heart, kidneys, and lungs of rats with experimental heart failure. Circulation, 92: 3105-3112.

7. J ohnston $\mathrm{Cl}$, Fabris $\mathrm{B} \&$ J andeleit $\mathrm{K}$ (1993). Intrarenal renin-angiotensin system in renal physiology and pathophysiology. Kidney International, 44 (Suppl): S59S63.
8. Lai KN, Leung J CK, Lai KB, To WY, Yeung VTF \& Lai FM (1998). Gene expression of the renin-angiotensin system in human kidney. J ournal of Hypertension, 16: 91102.

9. Casarini DE, Boim MA, Krieger-Azzolini MH, Krieger J E \& Schor N (1997). Angiotensin I converting enzyme activity in tubular fluid along the rat nephron. American J ournal of Physiology, 272: F405F409.

10. Chansel D, Dussaule JC, Ardaillou N \& Ardaillou R (1987). Identification and regulation of renin in human cultured mesangial cells. American J ournal of Physiology, 252: F32-F38.

11. Hadad SJ , Souza ERM, Ferreira AT, Oshiro 
MEM, Boim MA, Razvickas CV, Moura LAR \& Schor N (1995). FK 506: Effects on glomerular hemodynamics and on mesangial cells in culture. Kidney International, 48: 56-64.

12. Laemmli UK (1970). Cleavage of structural proteins during the assembly of the head of bacteriophage T4. Nature, 227: 680-685.

13. Schalekamp MA \& Derkx Frans HM (1993). Biochemistry of prorenin. In: Robertson J IS \& Nicholls MG (Editors), The Renin-Angiotensin System. Gower Medical Publishing, London, UK.

14. Hsueh WA, Do YS \& Wang PH (1990). Observations on the renal processing and sorting of prorenin. Canadian J ournal of Physiology and Pharmacology, 69: 13271330.

15. Hsuesh WA \& Baxter J D (1991). Human prorenin. Hypertension, 17: 469-479.

16. Taugner R \& Hackenthal E (1988). On the character of the secretory granules in juxtaglomerular epithelioid cells. Interna- tional Review of Cytology, 110: 93-102.

17. Taugner R, Kim SJ, Murakami K \& Waldherr R (1987). The fate of prorenin during granulopoiesis in epithelioid cells: Immunocytochemical experiments with antisera against renin and different portions of the renin prosegment. Histochemistry, 86: 249-253.

18. Dzau VJ \& Kreisberg J (1986). Cultured glomerular mesangial cells contain renin: Influence of calcium and isoproterenol. J ournal of Cardiovascular Pharmacology, 10 (Suppl): S6-S10.

19. Shenoy U \& Cassis L (1997). Characterization of renin activity in brown adipose tissue. American J ournal of Physiology, 272: C989-C999.

20. Hackenthal E, Paul M, Ganten D \& Taugner R (1990). Morphology, physiology and molecular biology of renin secretion. Physiological Reviews, 70: 10671116.

21. J ones CA, Petrovic N, Novak EK, Swank RT, Sigmund C \& Gross KW (1997). Bio- synthesis of renin in mouse kidney tumor As 4.1 cells. European J ournal of Biochemistry, 243: 181-190.

22. Carey RM, McGrath E, Pentz ES, Gomez RA \& Barrett PQ (1997). Biomechanical coupling in renin-releasing cells. J ournal of Clinical Investigation, 100: 1566-1574.

23. Sealey J E, White RP, Laragh J H \& Rubin AL (1997). Plasma prorenin and renin in anephric patients. Circulation Research, 41: 17-21.

24. Lenz T, Sealey JE, Maack T, J ames GD, Marion D \& Laragh J H (1991). Half-life, hemodynamic, renal and hormonal effects of prorenin in cynomolgus monkeys. American J ournal of Physiology, 260: R804-R810.

25. Muller DN, Hilgers KF, Mathews $S$, Breu V, Fischli W, Uhlmann R \& Luft FC (1999). Effects of human prorenin in rats transgenic for human angiotensinogen. Hypertension, 33: 312-317. 